each person took to complete the examination and the reject rate.

Mr. D. Wallis (Admiralty) emphasized some of the more important aspects of the papers. $\mathrm{He}$ pointed out that when signal frequency was increased, performance was improved in terms of probability of detection; indeed, the percentage success rose from about 40 to 90 per cent. But the absolute number of signals missed remained about the same, that is, 4 per hour, in the experiment under discussion ${ }^{1}$. Thus, if missing a signal was due to a fluctuation of attention, then these brief but serious lapses might be thought to occur at the same rate whatever the speed of signal presentation.

Mr. Wallis also saw a wide application of the technique described by Mr. Elliott, as this enabled an investigator to sample the precise level of vigilance throughout lengthy periods.

Among the various methods of improving performance in vigilance or inspection tasks the most effective in practice was the use of two operators at the same time, since the lapses suffered by two individuals were uncorrelated in time. In a recent study, Mr. Wallis had found that detection probabilities could be doubled by this approach. There was also the possibility of transfer from tasks specially designed to maintain vigilance to the actual task. Finally, there was the possibility that some people who liked to be quiet and alone might be better at vigilance tasks that require this than would more extroverted people.

Dr. P. Bakan (U.S. National Science Foundation) discussed his experiments on vigilance ${ }^{18}$. The occurrence of performance decrement over time was a result of an increase in the effective threshold for the discrimination required for the task. Repeated effective threshold measurements for the detection of occasional brighter flashes had shown that the required increase in intensity had to be raised after $15 \mathrm{~min}$. Variables related to sleep were also related to a loss of vigilance in performance tasks. Monotonous environments might produce either of these states, while amphetamine sulphate could counteract them. Moreover, physiological changes such as electroencephalogram changes and reduction of muscle potentials were common to both states. However, the subject in a vigilance task would usually make efforts to keep awake by self-generated stimuli, for example, the characteristic increase in restlessness, singing or daydreaming. It was important also for the experimenter to try to raise vigilance by introducing external stimuli in order to avoid a state of sensory depriva- tion $^{19}$. Such external stimulation could be irrelevant to the particular vigilance task, yet had to be compatible with it.

Mr. D. C. Fraser (Institute of Aviation Medicine) said that three conditions were needed in a vigilance task: (1) the presence of neutral signals which had to be disregarded but throughout which the significant signals were randomly interspersed; (2) stress conditions were also required in terms of speed, load, duration, etc.; (3) knowledge of results had to be minimal. T'ests of effective threshold were therefore of a different nature from the classical vigilance test. Two kinds of vigilance had been found, the alertness needed throughout a long test to detect the occasional significant signals among many other slowly presented signals, and that needed in a short test for detecting the occasional signal among many rapid neutral signals.

Actual sampling during the work itself was even more promising than effective threshold techniques. Recent experiments at Farnborough had shown that vigilance fell off after $40 \mathrm{~min}$.- which was very close to the earlier findings ${ }^{4}$.

A full study was now needed of the relationships between vigilant behaviour and neurophysiological measures. The chairman of the meeting (Prof. J. Drever) had developed electroencephalogram tech. niques which Mr. Fraser suggested should be used to detect changes in the neurophysiological pattern during vigilance tasks.

N. H. MaCKWorth

1 Deese, J., Psychol. Rev., 62, 359 (1955).

${ }^{2}$ Baker, C. H., M.R.C. App. Psych. Unit Rep. No. 277 (1956) (unpublished).

${ }^{3}$ Wratt, S., Inspection Processes in Industry, Indust. Health Res. Bd. Rep. No. 63 (H.M. Stationery Office, 1932).

- Mackworth, N. H., Researches on the Measurement of Human Performance, M.R.C. Special Rep. Series No. 268 (H.M Stationery Óffice, 1950).

${ }^{5}$ Broadbent, D. E., Psychol. Rev., 60, 331 (1953).

- Whittenburg, J. A., Ross, s., and Andrews, T. G., "Perceptual and $109(1956)$

'Adams, J. A., J. Exp. Psychol., 52, 204 (1956).

${ }^{8}$ Saldanha, E. L., M.R.C. App. Psych. Unit Report No. 243 (1956) (unpublished).

'Broadbent, D. E., Brit. J. Psychol., 63, 295 (1953).

${ }^{10}$ Pepler, R. D., M.R.C. App. Psych. Unit Rep. No. 156 (1953) (u. C. Qur

Quart. J. Exp. Psychol., 5, 31 (1953).

12 Wilkinson, R. T. (personal communication).

${ }^{2}$ Siddall, G. J., and Anderson, D. M., Quart. J. Exp. Psychol., 7, 159 (1955).

${ }^{14}$ Adams, J., J. Exp. Psychol., 49, 390 (1955).

${ }_{15}$ Fletcher, C. M., and Oldham, P., Brit. J. Indust. Med., 6, 168 (1949).

16 Fletcher, C. M., A.M.A. Arch. Indust. Health, 11, 17 (1955).

${ }_{17}$ Yerushalmy, J., Diseases of the Chest, 24, 133 (1953).

18 Bakan, P., J. Exp. Psychol., 50, 387 (1955).

10 Anon., Brit. Med. J., 1224 (Nov. 24, 1956).

\title{
OBITUARIES
}

\section{Dr. H. R. Kraybill}

Henry Reist Kraybix,, who died in Chicago on September 30 at the age of sixty-five after several months illness, was particularly well known for his research studies on meat and meat products over the past fifteen years.

After graduating in agricultural chemistry at Pennsylvania State College in 1913, Dr. Kraybill took his doctorate at the University of Chicago in 1917. He organized and developed the Departments of Agricultural Chemistry first in the University of New Hampshire from 1919 until 1924 and then in the Purdue University from 1926 until 1941. During this period, he also served as State chemist for New Hampshire and Indiana and held appointments at the Boyce Thompson Institute and the United States Department of Agriculture.

He returned to Chicago in 1941 as director of the Department of Scientific Research of the American Meat Institute and as professorial lecturer in the 
Department of Biochemistry at the University of Chicago. When the American Meat Institute Foundation was formed in 1947 , it was a natural consequence that he should become its first director of research and education. In 1955 he became in addition vicepresident of the research organization of the Institute. At different periods, he held office as president of the Association of Agricultural Chemists, the American Association of Feed Control Officials, and the American Society of Plant Physiologists, and as chairman of the Division of Agricultural and Food Chemistry of the American Chemical Society.

From his earlier work in the fields of plant biochemistry and physiology, Kraybill turned in 1941 to pioneer work in the chemistry of meat and meat products. One of his most important contributions in this field was the discovery and development of two antioxidants for animal fats which not only inhibited development of oxidative rancidity in the fat alone but also inhibited the development of rancidity in manufactured products containing the fat. He learned just before his death that for this work he had been chosen for the Dodge and Olcott Award for 1956.

Earlier in the year, the Purdue University had conferred on him an honorary degree of doctor of science in recognition of his service to the University and his achievements as a scientist, teacher and administrator in the science of agriculture.

Dr. Kraybill was of a quiet, retiring disposition and always gave a very warm welcome to visitors from Britain to the United States. J. G. SHARP

\author{
Prof. James M. Sherman
}

Prof. James M. Sherman, professor of bacteriology in Cornell University since 1923 and head of the University's Department of Dairy Industry, died on November 5 at the age of sixty-six. He had relinquished his administrative duties as departmental head on July 1, 1955, in order to devote his full time to writing and research.

Prof. Sherman was a graduate of the North Carolina State College and the University of Wisconsin. Before going to Cornell, he held teaching posts in the University of Wisconsin and Pennsylvania State University, and he was bacteriologist in the U.S. Department of Agriculture during 1917-23. He was a past-president of the American Dairy Science Association and of the Society of American Bacteriologists.

Prof. Sherman was the author of more than a hundred research papers, and published a book on laboratory methods in bacteriology and a monograph on the streptococci. His major research work concerned general biological studies of micro-organisms, systematic studies of some of the important groups of bacteria, especially the streptococci, and investigations of the micro-organisms of importance in milk, food products, soil and industrial fermentations. He served as editor-in-chief of the Journal of Bacteriology (1944-51), and associate editor of the Bacteriological Reviews (1937-44), and at the time of his death he was a member of the editorial committee of the "Annual Review of Microbiology".

\section{NEWS and VIEWS}

Agriculture in the University of Melbourne: Sir Samuel Wadham

Sir Samuel Wadham retires at the end of 1956 from the chair of agriculture in the University of Melbourne after thirty years in that position. Sir Samuel took his first degree at Cambridge (Christ's College), and after the First World War, when he served in the Middle East, he returned to Cambridge as a senior demonstrator in botany. He was invited in 1926 to go to Melbourne as the first professor in a reorganized Department of Agriculture. During his occupancy of the chair some four hundred students have taken their degrees (B.Agr.Sc.), and his graduates comprise a hundred of the scientific staff of the Victorian Department of Agriculture. His own career has been especially marked by the calls that have been made by governments on his skilled services as an adviser in the field of land utilization ; in particular, he played a major part in two Commonwealth Commissions, one into the wheat, flour and bread industries during the mid-1930's, and the other the Rural Reconstruction Commission, 1943-45, which advised on policies of post-war land settlement. The chief lines of work carried out in the School under his direction and stimulus have been surveys of soil and land utilization and standards of living. His "Land Utilization in Australia", first produced in 1939 in collaboration with Prof. G. L. Wood, has become an accepted text-book, and is now in its third edition. Apart from his work for agriculture, Sir Samuel has played a major part as a university administrator and in interpreting the university to the public. Through personal visits and regular broadcasts he has become widely known and loved throughout the Australian agricultural community. His exceptional services to Australia were recognized by the award of a knighthood in the New Year Honours in 1956.

\section{Dr. H. C. Forster}

DR. H. C. Forster, who succeeds to the Melbourne chair of agriculture, is a graduate of the school of which he now becomes the head. His published work deals with factors determining the yield of wheat, and his degree of Ph.D. in statistics was taken at the University of Iowa during the tenure of a Commonwealth Fund Fellowship in 1935-37. He first joined the Victorian Department of Agriculture, in which he became senior cereal research officer, and for many years he has been a part-time lecturer on cereal crops in the University's School of Agriculture. $\mathrm{He}$ was president of the Australian Institute of Agricultural Science in 1955, and chairman of the central executive of War Agricultural Commititees during the Second World War. Since 1949 he has been assistant executive officer of the Commonwealth Scientific and Industrial Research Organization. He brings to his new post an exceptionally wide knowledge of agriculture and agricultural research throughout the Commonwealth.

\section{Awards for University Education}

IN a debate in the House of Commons on November 29 on university awards, Mr. J. C. Jennings, Mr. F. Mulley and Lord Balniel pressed for the establishment of a working party to examine the 